\title{
ECOLOGICAL AND DISTRIBUTION TRAITS OF THE LARGE WHITE-FACED DARTER Leucorrhinia pectoralis (Charpentier, 1825) IN SLOVAKIA
}

\author{
ZUZANA ŠÍBLOVÁ $\otimes^{1,2}$, STANISLAV DAVID ${ }^{1,2}$, MILENA MOYZEOVÁ ${ }^{1}$ \\ ${ }^{1}$ Institute of Landscape Ecology, Slovak Academy of Sciences, Štefánikova 3, P.O. Box 254, 81499 Bratislava, Slovak Republic; e-mail: zuzana.siblova@savba.sk, \\ milena.moyzeova@savba.sk, stanislav.david@savba.sk \\ ${ }^{2}$ Department of Ecology and Environmental Studies, Faculty of Natural Sciences, Constantine the Philosopher University in Nitra, Tr. A. Hlinku 1, 94901
} Nitra, e-mail: zuzana.siblova@savba.sk

Corresponding author

Received: 5 May 2021 / Accepted: 30 July 2021

\begin{abstract}
Š́blová Z., David S., Moyzeová M.: Ecological and distribution traits of the large white-faced darter Leucorrhinia pectoralis (Charpentier, 1825) in Slovakia. Ekológia (Bratislava), Vol. 40, No. 3, p. 248-257, 2021.

The dragonfly Leucorrhinia pectoralis was recorded in Slovakia at 38 sites in 112 findings and there were 707 imagoes. Reproduction was confirmed in seven sites by finding of 35 larvae and exuviae. The highest number of sites with the occurrence of L. pectoralis is located in the Záhorská nížina lowland; most sites in Slovakia are located at an altitude of $213-351 \mathrm{~m}$. L. pectoralis was recorded together with 49 species of dragonflies, and the average number of $L$. pectoralis was 9.56 individuals per site. It occurs in the communities as a dominant species (9.5\%) together with eudominants Coenagrion puella, C. hastulatum and Libellula quadrimaculata. By non-metric multidimensional scaling (NMDS), we found a coenotic correlation to peat species Libellula quadrimaculata, Leucorrhinia rubicunda, L. dubia and Sympetrum danae. By redundancy linear analysis (RDA), we found a Monte Carlo permutation test to make a non-random contribution to the explained variability of seven factors $(\mathrm{p}=0.012-0.034)$. L. pectoralis statistically significantly prefers habitats in the forest landscape $(\mathrm{r}=0.62, \mathrm{p}=0.0063)$, the presence of vegetation $(\mathrm{r}=0.94, \mathrm{p}=0.0003)$ and peatbogs $(\mathrm{r}=0.61$, $p=0.0058$ ). We did not confirm a significant correlation to altitude. Based on easy determination, territoriality (especially males) and bioindicative sensitivity of larvae, L. pectoralis is accepted as an umbrella species. L. pectoralis has a high dispersion potential and is suitable for creating the metapopulation character of local populations, which is important for the conservation management of the species.
\end{abstract}

Key words: dragonfly, dispersion potential, assemblages, wetland, umbrella species.

\section{Introduction}

The World Odonata List (Schoor, Paulson, 2020) lists 14 taxa of the genus Leucorrhinia (family Libellulidae). Euro-Siberian (Palearctic) distribution with occurrence in Europe has five species (Boudot, Kalkman, 2015): Leucorrhinia albifrons (Burmeister, 1839), L. dubia (Vander Linden, 1825), L. caudalis (Charpentier, 1840), L. pectoralis (Charpentier, 1825) and $L$. rubicunda (Linnaeus, 1758). These species also occur and reproduce in Slovakia (David, Šácha, 2019). Dragonfly L. pectoralis has an islet-like occurrence in Central Europe, linked to the localization of suitable peatland habitats. Numerous breeding populations of L. pectoralis are in Poland and the Baltic republics (Kalninš, 2007). Dragonfly L. pectoralis inhabits nutrient-poor dystrophic to mesotrophic bog marshes, transitional peatbogs, uplands, forest lakes with littoral-type vegetation, ponds with Phragmites australis vegetation, grounded canals and dead peattype river branches. The authors (Dijkstra, Lewington, 2006; Dolný et al., 2008; Sternberg, Buchwald, 2000) equally attach great importance to the presence of littoral vegetation and the growth of higher vegetation around the water body, which pro- vides protection of imagoes from the wind, and imago males like to use it to rest. A specific case of the habitat is flooded mine areas after hard coal mining in the Karviná region in Silesia (Czech Republic). Harabiš et al. (2006) found here 45 species of dragonflies, several of which belong to sphagnophilic, endangered or protected species, for example, Somatochlora flavomaculata, Sympetrum danae, Leucorrhinia pectoralis and L. rubicunda. Larvae of $L$. pectoralis prefer peat habitats in the middle successive stage of overgrowth with vegetation with stands of Utricularia sp., Ceratophyllum sp. and water depths up to $50 \mathrm{~cm}$ (Sternberg, Buchwald, 2000; Rannap et al., 2011). Boudot and Kalkman (2015) specify that the optimal habitats of Leucorrhinia pectoralis are regionally specific, and in this species, the habitat ecological niche is relatively wide.

For the species $L$. pectoralis, the metapopulation character of local populations with a high dispersion of imagoes and the search for new habitats is important. Jaeschke et al. (2013) report a maximum observed dispersion distance of $L$. pectoralis of $27 \mathrm{~km}$, depending on the two-year development of larvae. Imago flights between sites were also recorded throughout the season (Dolný, Harabiš, 2004; Harabiš, Dolný, 2012). In repro-

(C) The Author(s) 2021. This is an open access article distributed under the terms of the CC BY-NC-ND license.

https://content.sciendo.com/view/journals/eko/eko-overview.xml 
ductive habitats of $L$. pectoralis, the survival and abundance of populations are influenced by synergistic abiotic and biotic factors (Mauersberger, 2010; Boudot, Kalkman, 2015; Sternberg, Buchwald, 2000): grounding of aquatic habitats and vegetation overgrowth by ecological succession and direct habitat destruction. Fish predation may be locally important, especially European perch (Perca fluviatilis) (Mauersberger, 2010). The abundance of local populations can thus vary considerably over the years. During one season, there may be only a few individuals at the site, but under suitable conditions, the number may increase to several hundred individuals at the same site in another year (Dolný et al., 2008).

The concept of umbrella/surrogate species has proved to be a useful tool for biodiversity protection. By protecting the umbrella species, we also indirectly protect other species (Lambeck, 1997). According to Seddon and Leech (2008), the concept of umbrella species is not a simple tool; it requires knowledge of the ecology of a potential umbrella species as well as co-occurring species. Kietzka et al. (2019) present some properties of umbrella species, and several are identical with the properties of bioindicative species (easy determinability, territoriality and sensitivity to changes). However, criticism of the concept of surrogate species pointed to a lack of quantification of their selection. Therefore, an umbrella index was developed, which is the sum of three subindices [(i) co-occurrence with other species (PCS), (ii) number of sites where the species occurs (R) and (iii) susceptibility to anthropogenic species). This direction of umbrella species selection is being developed mainly in North America and East Asia (Kietzka et al., 2019). Based on bioindicative sensitivity, Czachorowski et al. (2000) identified umbrella species (Trichoptera, Heteroptera, Lepidoptera, Odonata, etc.) for different habitats of running and standing waters. From dragonflies (Odonata), it is also L. pectoralis for peatbogs.

The first published data on $L$. pectoralis from the territory of today's Slovakia come from Mocsáry (1896), and it states a finding from the vicinity of Kremnica and Štrba. The first confirmed occurrence is from 1961 (Trpiš, 1969) from the oxbow lake of Latorica River - Dlhé Tice near the village of Rad (1961, 2 males, leg. M. Trpiš, rev. S. David). Most records of the occurrence of L. pectoralis come from western Slovakia, the geomorphological unit of Záhorie (e.g. Šácha, Š́bl, 2000; Šíbl, 2001; Blaškovič, 2007). This area is characterized by the occurrence of peatbogs, which are suitable habitats of the species (Šíblová, Moyzeová, 2019; Kalivodová et al., 2018). The latest incidence data are the result of monitoring L. pectoralis as a species of Community interest (Habitats Directive, Annex 4).

The synergistic effect of risk factors results in the evaluation of $L$. pectoralis as an endangered species. The Global Red List (iucnredlist.org) places the species in the least concern (LC) category with the population trend of the species as stable. The European Red List of Dragonflies (Kalkman et al., 2010) also evaluates the species in the LC category, but with a declining population trend. The conservation assessment of $L$. pectoralis for the Carpathian mountain range was prepared by Šácha et al. (2014). In the Slovak and Czech parts of the Carpathians, L. pectoralis is included in the vulnerable (VU) category, in Polish and Ukrainian in the data deficient (DD) category, in Hungarian in LC category and in Romanian in not evaluated (NE) category. Due to its reproduction on endangered habitat types, L. pectoralis is assessed as a species of Community interest and included in the Berne Convention (Appendix II) and the Habitats Directive (Council Directive 92/43/EEC, Annexes II and IV). This implies the obligation to monitor the species and evaluate its 'favourable condition. The results of the performed monitoring for the years 2013-2015 were processed by Šácha (2015a).

The aim of our study is to process the distribution, coenological characteristics, habitat preference and threatening factors of the population and habitats of $L$. pectoralis in the Slovak Republic on the basis of occurrence data.

\section{Material and methods}

We compiled a database of $L$. pectoralis findings from our own research, published and unpublished sources. After removing incomplete data, we obtained 112 records, which is the number of $L$. pectoralis individuals found in one day at the site. The data come from 38 sites ( $\mathrm{n}=742$ individuals, 707 imagoes, 25 exuviae and 10 larvae) from Slovakia from 1961 to 2020. The data were obtained by semi-quantitative methods of faunistic research. The sites were visited with different frequency, and the number of larvae and exuviae is low. An exception is the data obtained by the methodology of biomonitoring of L. pectoralis as an annex species, originating from eight sites (Šácha, 2015b).

We analysed the finding data by descriptive statistics, and we tested the normality of the hypsometric distribution of sites by the Shapiro-Wilk test in the Statistika.cz program (StatSoft, 2004). For species, we calculated their dominance. Dominance and the categories are reported according to Losos et al. (1985). Other indices (Simpson's index N2, Shannon entropy $\mathrm{H}^{\prime}$, the maximum value of Shannon entropy $\mathrm{H}_{\max }$ ) were exported from the Canoco5 program (ter Braak, Šmilauer, 2012). We analysed the structure of the group of dragonflies co-occurring with $L$. pectoralis in the Canoco5 program (ter Braak, Šmilauer, 2012). From the species matrix (50 species, 38 sites), we removed sites with the occurrence of only L. pectoralis and species with the occurrence of two or less individuals, thus eliminating their accidental occurrence. We choose the choice of ordination methods according to the highest length of the environmental gradient (it is in standard deviation (SD) units). We used robust non-metric multidimensional scaling (NMDS) using the Bray-Curtis dissimilarity index for species structure analysis. In the second step of NMDS, Canoco5 uses principal component analysis (PCA) to rotate the ordination axes in order to maximize the variance of the case score. We determined the loss of information according to the stress criterion value (SCV), and it takes a value from 0 to 1 (Šmilauer, Lepš, 2014). For species matrix sites, we derived 17 environmental variables that determine: (a) vegetation complexity (vegetation complexity - aquatic and swamp vegetation or tall riparian vegetation - littoral stands of Phragmites australis, Typha sp.), (b) habitat types (ponds, sand/gravel pits, regulated brooks, peatbogs, paleopotamals, interdunal ponds), (c) land use (forests, arable land, arable land/forests) and (d) hypsometric and ecological characteristics of the site (altitude; successional stages of hydrosere - initial, mediate, climax; metapopulation character of the site yes/no; water-level stability - permanent/ temporal). Statistical significance $\left(\mathrm{p}_{\alpha}=0.05\right)$ of environmental factors was tested by Monte Carlo permutation test with 499 permutations. Null hypothesis $\left(\mathrm{H}_{0}\right): \mathrm{i}$ - altitude values of $L$. pectoralis sites have a normal distribution and ii - species groupings 


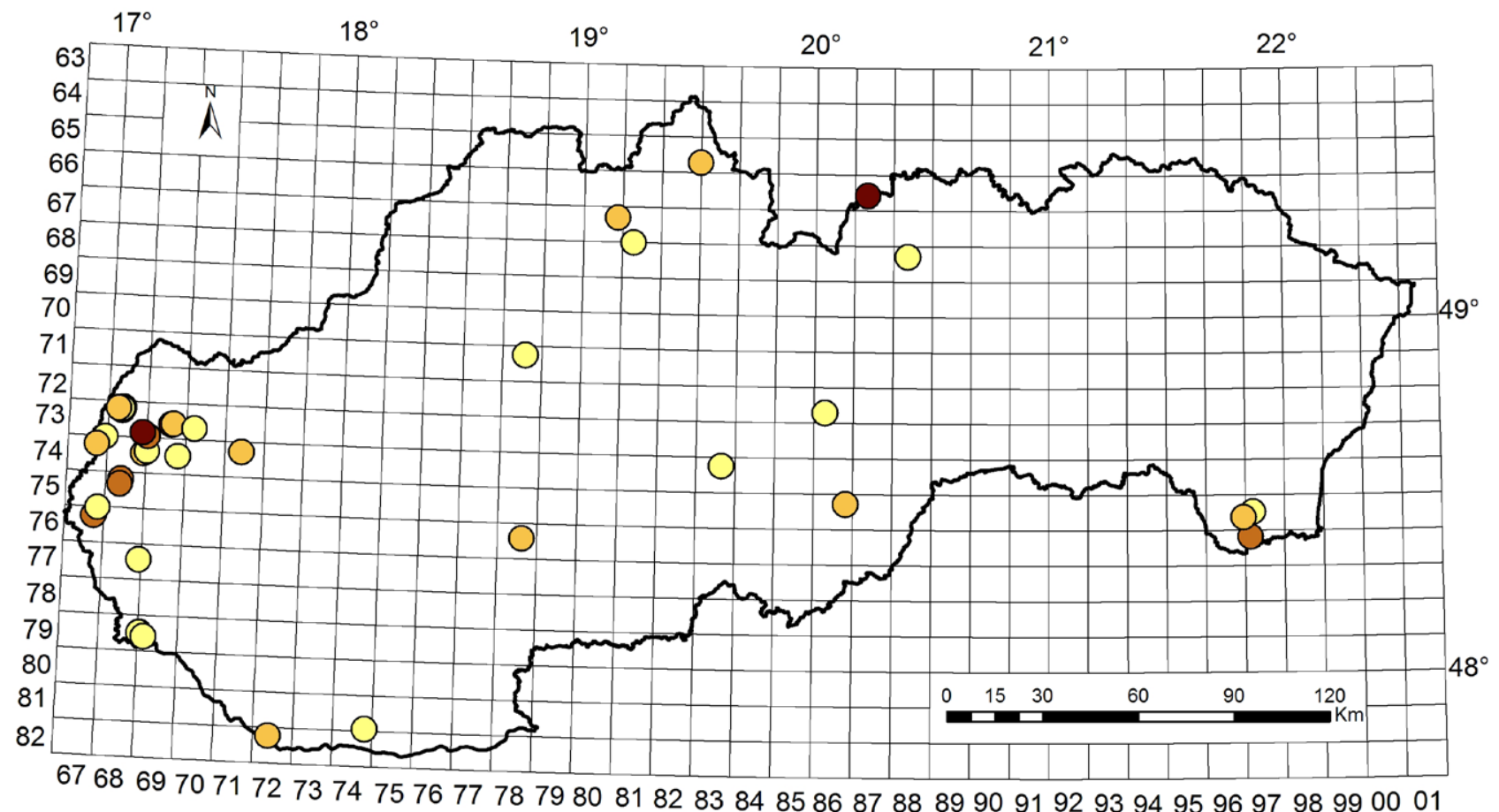

Number of specimens on localities of $L$. pectoralis

$1-4$

$5-26$

$27-69$

$70-118$

Fig. 1. Distribution of sites $(\mathrm{n}=38)$ and numbers of Leucorrhinia pectoralis individuals in Slovakia in the network of the Slovak Fauna Database (DFS), the grid has a size of $11 \times 12 \mathrm{~km}$, and we made the map in the ArcMap 10.1 program (ESRI, 2011).

are independent of selected explanatory variables of their sites. We measured the success of the analysis by the value of the coefficient of determination $\left(\mathrm{R}^{2}\right)$ and its adjusted value $\mathrm{R}_{\text {adj }}^{2}$. We verify the tightness of the mutual relationship (correlation) of environmental factors by non-parametric Spearman correlation coefficient, and the input is a correlation matrix from Canoco5 (log. file, $\left.p_{\alpha}=0.05\right)$. We evaluate the tightness of a linear bond expressed by the $r$ coefficient according to Conelly (2012): strength of correlation $r<0.2$ slight, $r$ $=0.2-0.4$ low, $\mathrm{r}=0.4-0.7$ moderate, $\mathrm{r}=0.7-0.9$ high and $\mathrm{r}>0.9$ very high. We specify the correlation between species and environmental characteristics by a generalized linear model (GLM) with a Poisson distribution. As response variables, we use the 'target species' L. pectoralis, and we test separately explanatory variables.

\section{Results}

\section{Count of specimens and hypsometric analysis of L. pec- toralis}

For the processing of autecological analysis of L. pectoralis, we used a data set of 112 findings, 742 individuals from 38 sites (Fig. 1, Appendix). Autochthonous occurrence (reproduction) was confirmed only in seven sites: at western part of Slovakia in Šajdíkové Humence (4Ex, loc. 11), Šaštín (2Ex) and Lakšárska Nová Ves (2L); at northern part in Zázrivá (8Ex), Klin (3L) and Osturňa (11Ex, 2L); and at middle Slovakia in Detvianska Huta (3L).
Using descriptive statistics (Table 1), we evaluated the number of individuals (NS) of $L$. pectoralis for the finding records (n $=112$ ). The values of variability and symmetry indicate a violation of the normality of the distribution of values (numbers of individuals), which was confirmed by the Shapiro-Wilk test ( $\mathrm{p}=$ 0.0000 ). Average number of individuals recorded in one day at a given site $\bar{x}=6.63$, minimum value $=1$ and maximum value $=47$ (NS, Table 1). Different numbers of individuals indicate high values of the SD $=8.09$. The symmetry (skewness) $\gamma_{1}=2.49$ is positive (low numbers of individuals predominate), and the spike (kurtosis) $\gamma_{2}=7.33$ is also positive (if it is a spiky distribution, the values are concentrated around the median). Hypsometric distribution of sites $(\mathrm{n}=38) \mathrm{L}$. pectoralis has an average value of $\bar{x}=282 \mathrm{~m}$ above sea level ( $\mathrm{m}$ a.s.l.), minimum value $=98 \mathrm{~m}$ a.s.l. and maximum value $=863 \mathrm{~m}$ a.s.l. (ALTI, Table 1 ). The confidence altitude interval around the diameter is from 213 to $351 \mathrm{~m}$ a.s.l. and SD $=209.69 \mathrm{~m}$ a.s.l. The variability values (minimum and maximum values and SD) indicate a violation of the normality of the distribution of altitude values, which was confirmed by the Shapiro-Wilk test $(\mathrm{p}=0.0000)$.

\section{Synecological characteristics of odonatocoenosis with $L$. pectoralis}

In the data set of species from 38 sites, we found the occurrence of $L$. pectoralis together with another 49 species of dragonflies. From the data set for synecological analysis, we removed 11 sites 
Table 1. Descriptive statistics of findings, hypsometric distribution and co-occurrence of $L$. pectoralis with other species.

\begin{tabular}{|c|c|c|c|c|c|c|c|c|c|c|c|}
\hline & $\mathbf{n}$ & Average & $\mathbf{- 9 5 \%}$ & $\mathbf{+ 9 5 \%}$ & Med & Mod & Min & Max & SD & Skew & Kurt \\
\hline NS & 112 & 6.63 & 5.11 & 8.14 & 3.50 & 1 & 1 & 47 & 8.09 & 2.48 & 7.33 \\
\hline ALTI & 38 & 282 & 213.08 & 350.92 & 199 & 200 & 98 & 863 & 209.69 & 1.46 & 1.16 \\
\hline ASSE & 27 & 9.59 & 7.92 & 11.27 & 9 & 4 & 4 & 18 & 4.24 & 0.39 & -0.94 \\
\hline
\end{tabular}

Notes: NS, number of specimens on each samples; n, number of records found; ALTI, altitude of sites; n, number of sites for the assessment of their altitude; ASSE, assemblage of L. pectoralis; $\mathrm{n}$, number of sites for evaluation of cenotic structure; SD, standard deviation; Skew, skewness; Kurt, kurtosis.

Table 2. Descriptive statistics, species richness and diversity of 27 sites (samples) of the habitat preference Leucorrhinia pectoralis; at sites 5 , $11,14,25,28$ and 31, the reproduction of $L$. pectoralis (grey lines) was found. For the site 27 (Detvianska Huta), indices were not calculated, and the occurrence of only L. pectoralis was confirmed.

\begin{tabular}{|c|c|c|c|c|c|c|c|c|}
\hline Samples & Average & Count & RelCount & Total & N2 & $\mathbf{H}^{\prime}$ & LogCount & Evenness \\
\hline 1 & 4.35 & 12 & 0.30 & 174 & 4.45 & 1.82 & 2.48 & 0.73 \\
\hline 2 & 0.38 & 9 & 0.23 & 15 & 7.26 & 2.08 & 2.20 & 0.95 \\
\hline 5 & 0.33 & 4 & 0.10 & 13 & 2.68 & 1.16 & 1.39 & 0.83 \\
\hline 7 & 0.35 & 7 & 0.18 & 14 & 4.90 & 1.75 & 1.95 & 0.90 \\
\hline 8 & 13.63 & 13 & 0.33 & 545 & 3.78 & 1.75 & 2.56 & 0.68 \\
\hline 11 & 13.05 & 18 & 0.45 & 522 & 5.73 & 2.06 & 2.89 & 0.71 \\
\hline 13 & 6.83 & 10 & 0.25 & 273 & 1.77 & 1.01 & 2.30 & 0.44 \\
\hline 14 & 1.53 & 11 & 0.28 & 61 & 6.78 & 2.11 & 2.40 & 0.88 \\
\hline 15 & 0.30 & 7 & 0.18 & 12 & 4.80 & 1.75 & 1.95 & 0.90 \\
\hline 16 & 0.13 & 4 & 0.10 & 5 & 3.57 & 1.33 & 1.39 & 0.96 \\
\hline 17 & 6.60 & 14 & 0.35 & 264 & 6.98 & 2.26 & 2.64 & 0.86 \\
\hline 18 & 1.63 & 6 & 0.15 & 65 & 3.71 & 1.50 & 1.79 & 0.84 \\
\hline 19 & 0.48 & 5 & 0.13 & 19 & 4.46 & 1.55 & 1.61 & 0.96 \\
\hline 20 & 3.88 & 11 & 0.28 & 155 & 3.62 & 1.51 & 2.40 & 0.63 \\
\hline 21 & 0.73 & 6 & 0.15 & 29 & 2.57 & 1.28 & 1.79 & 0.71 \\
\hline 22 & 0.25 & 4 & 0.10 & 10 & 2.94 & 1.22 & 1.39 & 0.88 \\
\hline 23 & 6.10 & 17 & 0.43 & 244 & 9.00 & 2.39 & 2.83 & 0.84 \\
\hline 25 & 42.03 & 15 & 0.38 & 1681 & 3.07 & 1.51 & 2.71 & 0.56 \\
\hline 26 & 2.88 & 8 & 0.20 & 115 & 5.13 & 1.77 & 2.08 & 0.85 \\
\hline 28 & 1.68 & 8 & 0.20 & 67 & 3.10 & 1.35 & 2.08 & 0.65 \\
\hline 29 & 0.88 & 5 & 0.13 & 35 & 1.76 & 0.92 & 1.61 & 0.57 \\
\hline 30 & 14.85 & 16 & 0.40 & 594 & 3.22 & 1.66 & 2.77 & 0.60 \\
\hline 31 & 16.35 & 14 & 0.35 & 654 & 3.18 & 1.59 & 2.64 & 0.60 \\
\hline 34 & 16.90 & 12 & 0.30 & 676 & 2.61 & 1.39 & 2.48 & 0.56 \\
\hline 35 & 4.38 & 10 & 0.25 & 175 & 5.26 & 1.82 & 2.30 & 0.79 \\
\hline 36 & 1.20 & 5 & 0.13 & 48 & 3.85 & 1.44 & 1.61 & 0.90 \\
\hline 38 & 3.50 & 8 & 0.20 & 140 & 1.94 & 1.05 & 2.08 & 0.50 \\
\hline
\end{tabular}

Notes: Total count of species $=40$; Average (sample average = total/total count of species); Count (count of species within samples); RelCount (relative count of species within samples = count/total count of species); Total (count of specimens within samples); N2 (Simpson index); $\mathrm{H}^{\prime}$ (Shannon entropy); LogCount (Hmax); Evenness.

with the occurrence of only L. pectoralis (27 sites remained) and 10 species of dragonflies, which occurred in the site in only one finding in the number of one and two specimens (40 species remained). The average number of species at the sites (including L. pectoralis) was $\bar{x}=9.59$, the minimum number of species at the site was 4 , and the maximum number was 18 (ASSE, Table 1 ). The slope is positive $\gamma_{1}=0.39$, low values slightly prevail over larger ones, the slope is negative $\gamma_{2}=-0.94$, and the values of the number of species are not concentrated around the mean value (Shapiro-Wilk test $\mathrm{p}=0.14485$ ).

Coenagrion puella ( $\mathrm{D}=37 \%$, eurytopic species), C. hastulatum ( $\mathrm{D}=13 \%$, sphagnophilous species) and Libellula quadrimaculata ( $\mathrm{D}=10 \%$, sphagnophilic species) were eudominantly represented in the community of dragonflies with Leucorrhinia pectoralis. The dominant species was only L. pectoralis $(\mathrm{D}=$ $9.5 \%)$. Subdominant were the species of standing, vegetated 


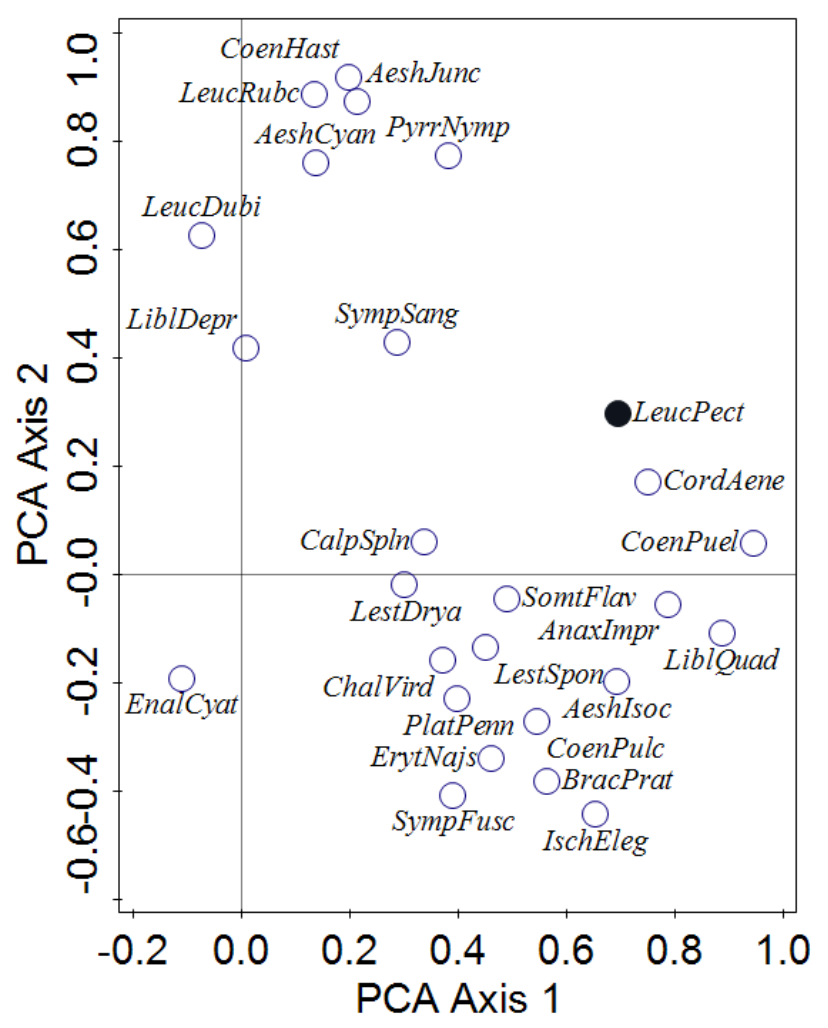

Fig. 2. Fit (26 species of dragonflies are shown) ordination graph principal component analysis of the species matrix Leucorrhinia pectoralis forms with the species Cordulia aenea and Coenagrion ornatum creates an isolated ordination cluster. The full names of the dragonflies are shown in Fig. 3.

waters Cordulia aenea, Ischnura elegans, Aeshna isoceles, Lestes dryas, Sympetrum sanguineum and Pyrrhosoma nymphula (D = $2.93-2.08 \%$ ). The other 30 dragonfly species were recedent and subrecedent species.

Using the Canoco5 program, we calculated descriptive statistics, species richness and species diversity of dragonfly communities with the occurrence of $L$. pectoralis for 27 sites (Table 2).

For ordination analysis, the species matrix had 27 localities and 40 species. With indirect detrended correspondence analysis (DCA), we found the length of the gradient on the 1st ordination axis $=2.77 \mathrm{SD}$ units. Since this is a short gradient, we performed an indirect (unrestricted) PCA. We used fitting with a species significance of $0.5 \%$, and 26 species are shown in the ordination graph (Fig. 2). The first ordination axes explain $36.49 \%$ of the variability of species data, the cumulative value of variability on axis $2=51.47 \%$ and on axis $4=69.34 \%$. In the fitted (0.5\%) PCA ordination chart of the species matrix, Leucorrhinia pectoralis correlates with Cordulia aenea and Coenagrion puella. Species Somatochlora flavomaculata, Anax imperator, Libellula quadrimaculata, etc. form a transition to a species-rich grouping of eutrophic aquatic habitat species. Contrary to expectations, Leucorrhinia pectoralis is not part of a grouping of sphagnophilic (peat) species of Coenagrion hastulatum, Aeshna juncea, Leucorrhinia rubicunda and the like.
As ordination analysis did not show the expected coenotic link to peatland species (and habitats) of dragonflies, we also performed a non-metric analysis of the species matrix by multidimensional scaling (NMDS). We used species scores (response variables) on four ordination axes from PCA. The resulting ordination graph (Fig. 3) confirmed the uniform distribution of species with the position of Leucorrhinia pectoralis near the intersection of the ordination axes. Although there is no significant coenotic preference, we identify a positive correlation to peat species such as Libellula quadrimaculata, Leucorrhinia rubicunda, L. dubia and Sympetrum danae. The stress score for the two selected dimensions $=0.16$ is the value of a good ordination model, and the good model is also confirmed by the values of species scores MNDS1 and NMDS2, which after PCA rotation almost coincides with the original NMDS scores (Fig. 3). Explained variability on the 1 st ordination axis $=59.1 \%$, and its fitted value $=57.2 \%$. The significance test confirmed the significance of NMDS1 and NMDS2 on the first two ordination axes (pseudo-F for axis $1=1.1$, axis $2=1.4, \mathrm{p}=0.002$ ).

The names of the dragonflies in the ordination graph are the same as in Fig. 2: AeshAffn, Aeshna affinis; AeshCyan, A. cyanea; AeshIsoc, A. isoceles; AeshJunc, A. juncea; AnaxImpr, Anax imperator; BracPrat, Brachytron pratense; CalpSpln, Calopteryx splendens; CoenHast, Coenagrion hastulatum; CoenPuel, C. puella; CoenPulc, C. pulchellum; CordAene, Cordulia aenea; CrocEr$y t$, Crocothemis erythraea; EnalCyat, Enallagma cyathigerum; EpitBimc, Epitheca bimaculata; ErytNajs, Erythromma najas; ErytVird, E. viridulum; ChalVird, Chalcolestes viridis; IschEleg, Ischnura elegans; IschPuml, I. pumilio; Lest Barb, Lestes barbarus; LestDrya, L. dryas; LestSpon, L. sponsa; LestVirn, L. virens; LeucCaud, Leucorrhinia caudalis; LeucDubi, L. dubia; LeuctPect, L. pectoralis; LeucRubc, L. rubicunda; LiblDepr, Libellula depressa; LiblFulv, L. fulva; LiblQuad, L. qudrimaculata; OrthAlbs, Orthetrum albistylum; OrthCanc, O. cancellatum; PlatPenn, Platycnemis pennipes; PyrrNymp, Pyrrhosoma nymphula; SomtFlav, Somatochlora flavomaculata; SympFusc, Sympecma fusca; SympDana, Sympetrum danae; SympFlav, S. flaveolum; SympSang, S. sanguineum; SympVulg, S. vulgatum.

\section{Habitat preference of L. pectoralis}

For the analysis of the binding of $L$. pectoralis to habitat types, we used the second table as in the synecological survey (27 sites and 40 species remained). We supplemented the evaluation of sites with the Simpson Diversity Index, the Shannon Entropy Index and other values obtained with the export statistics tool in the Canoco5 program (Table 2). For 27 sites, we derived 17 habitat characteristics (environmental variables), which are listed as significant due to the impact on dragonflies. We used constrained redundancy analysis (RDA) according to the gradient length value $(\mathrm{SD}=2.77)$. The analysis returned (log file) information on collinearity variables: interdunal ponds, arable land/forest, metapopulation - no, tall riparian vegetation and temporary type of water surface. The values of inflation factors were IF $<6.2$, only the factors complexity vegetation $=13.39$ and permanent water surface $=12.61$. Initial information on the statistical significance of the selected factors was obtained by a Monte Carlo permutation test (499 permutations) using the summarize effects of explanatory variables method. A non-random contribution to the explained variability was made by seven factors that were statis- 

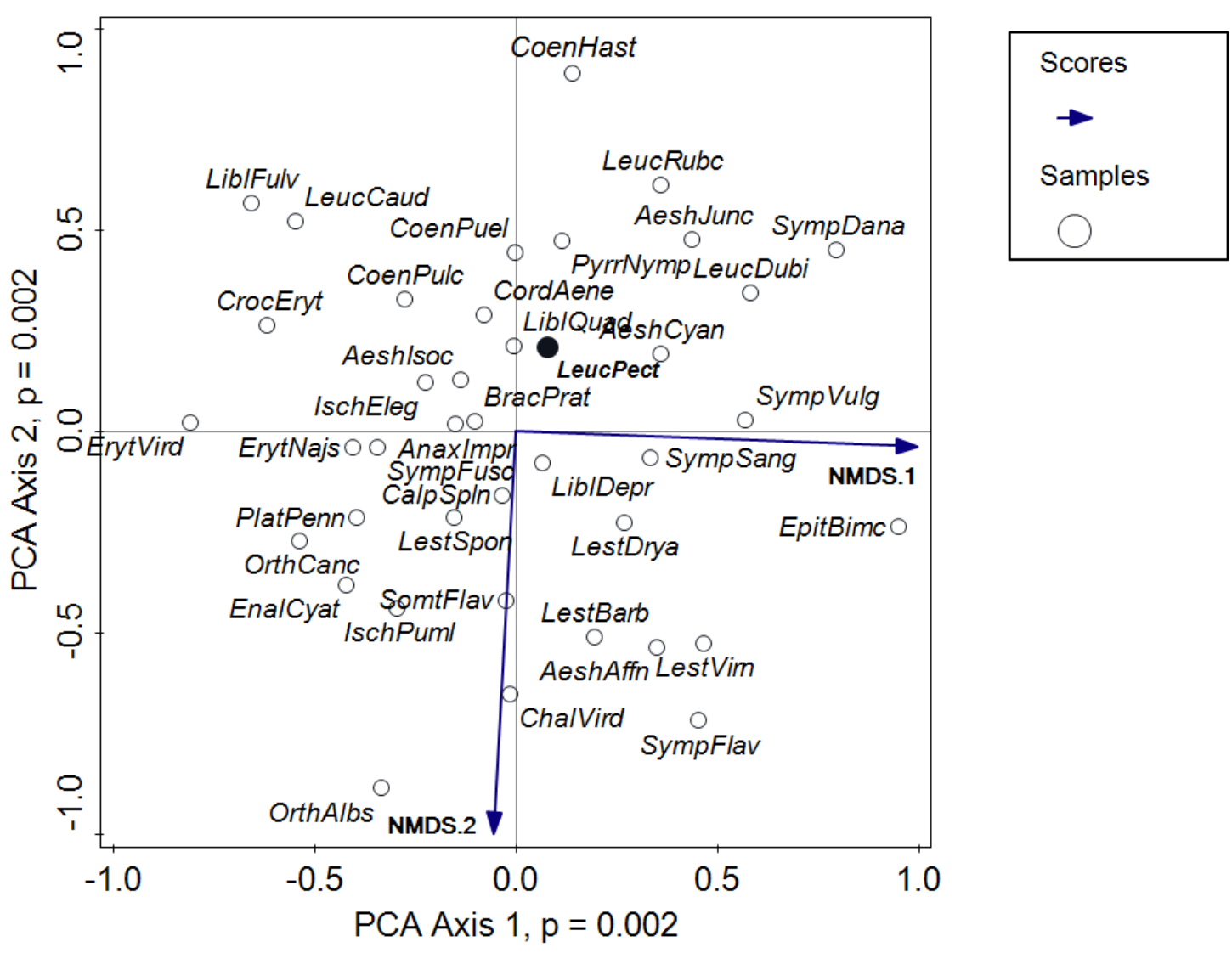

Fig. 3. Position of Leucorrhinia pectoralis in the NMDS ordination graph among dystrophic and eutrophic water habitats overgrown with vegetation with projected NMDS axes.

tically significant (pseudo-F $=3.2-2.3, \mathrm{p}=0.012-0.034$ ). After Bonferroni correction ( $\mathrm{a} /$ number of independent environmental characteristics), these factors were not statistically significant ( $\mathrm{p}$ $>0.204$ ). We selected factors with minimal mutual correlation using the forward selection of explanatory variables method, and only the factors forest (pseudo- $\mathrm{F}=3.2, \mathrm{p}=0.01$ ) and altitude (a.s.l.) (pseudo-F $=2.4, \mathrm{p}=0.03$ ) were statistically significant. After adjustment, we left six environmental variables in the analysis; their mutual correlation, correlation to ordination axes and species are shown in Fig. 4. The number of species 30 in the ordination chart is the result of their fitting with a significance of $1 \%$.

To evaluate the success of our model, we present the values of variability explained by the given ordination axis - eigenvalues ( 1 st axis $=0.15 ; 2$ nd axis $=0.10,4$ th axis $=0.02$ ). Cumulative variations in species data are as follows: 1 st axis $=14.54 \%$; 2 nd axis $=24.33 \%$ and 4 th axis $=29.75 \%$. The values of the fitted cumulative variance (variability of species data explained by our chosen environment variables) are as follows: 1 st axis $=45.27 \%$; 2 nd axis $=75.71 \%$ and 4 th axis $=92.59 \%$. The value of sum of all canonical eigenvalues $=0.32(=32 \%)$ is the variability of the file, which is explained by our selected environment variables. Canoco5 directly calculates the value of $\mathrm{R}^{2}$, and our selection of environmental factors captured $32.13 \%$ of the variability in the species data. However, the more accurate adjusted value of $\mathrm{R}^{2}{ }_{\text {adj }}=11.77 \%$ is significantly lower. The group of environmental factors, com- plexity, forest and peatbog are correlated together according to the direction and angle between the vectors (Fig. 4). Statistically significant $(\mathrm{p}<0.05)$ Spearman correlations are as follows: forest $\times$ complexity $(r=0.83)$, forest $\times$ peatbog $(r=0.089)$, the highest (negative) value is the factor forest $\times$ permanent $(r=-0.94)$.

Dragonfly $L$. pectoralis statistically significantly prefers habitats in the forest landscape (forest, $r=0.62, p=0.0063$ ), the presence of vegetation (complexity, $r=0.94, p=0.0003$ ) and peatbogs (peatbog, $r=0.61, p=0.0058$ ). The negative correlation is to the factor of permanent water surface (permanent, $\mathrm{r}=-0.92, \mathrm{p}=$ $0.00015)$, the factor pond $(\mathrm{r}=-0.35, \mathrm{p}=0.8472)$ and altitude (a.s.l., $r=-0.00, p=0.8472$ ). The last two factors are not statistically significant.

\section{Discussion}

Dragonfly L. pectoralis is a species with local and short-term mass occurrence in the site. In Slovakia, after 2000, the species was recorded at 35 sites, one to two flying individuals were recorded at eight sites. Only in seven sites was the reproduction of $L$. pectoralis confirmed by finding of larvae and exuviae. Different numbers of $L$. pectoralis sites are mentioned from Central Europe. For instance, Bernard et al. (2009) mentioned 283 sites from Poland occurring after 1990; Manci and Popuscu (2016) published from Romania only three recent breeding sites from the southern part 


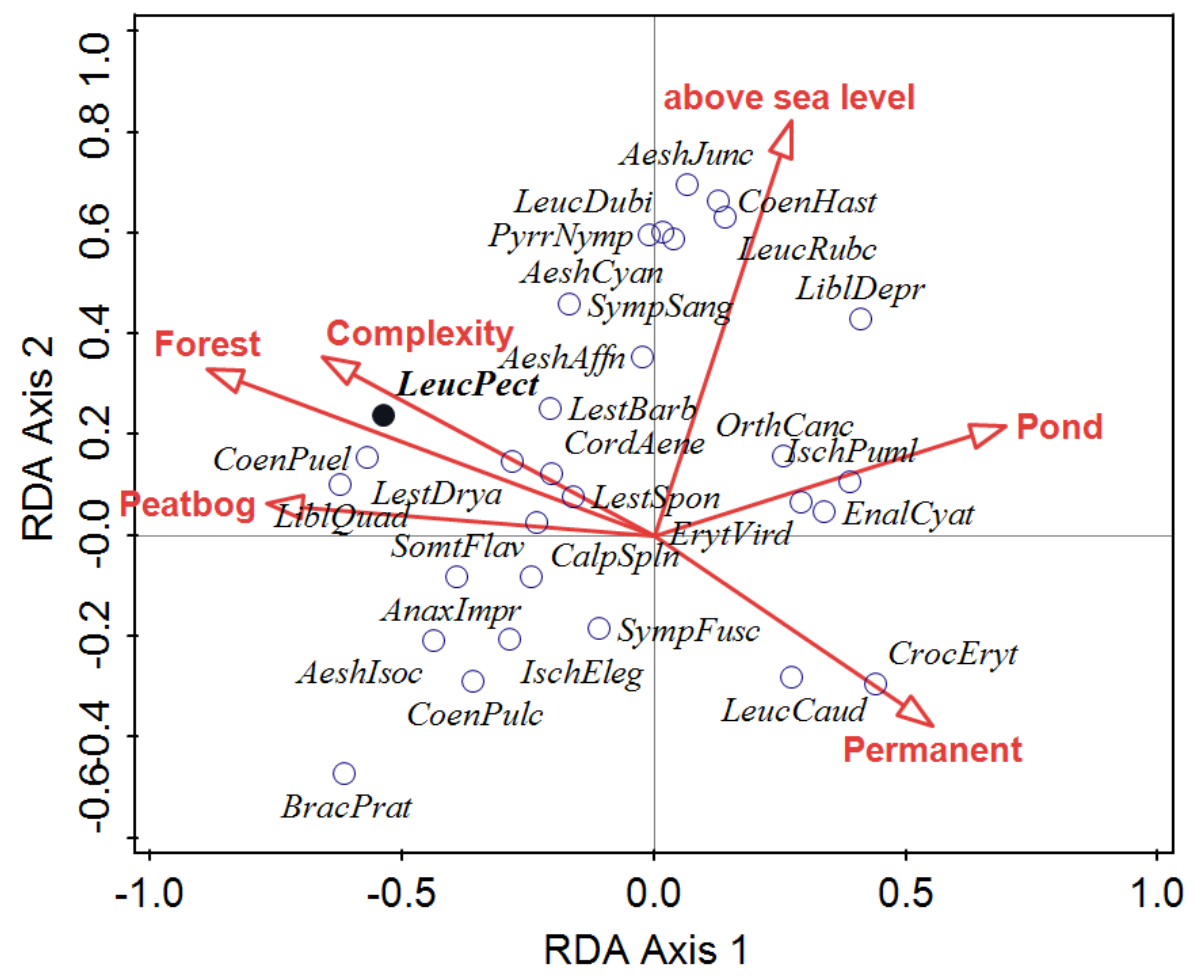

Fig. 4. Analysis of selected habitat factors of sites and species of odonatocoenosis with the onset of Leucorrhinia pectoralis.

of the Carpathians, from an altitude of $1000 \mathrm{~m}$ a.s.l. In Slovakia, the highest number of individuals was recorded at the Šaštín site (NR Vanišovec). In 2001, T. Blaškovič (in litt.) recorded 34 imagoes here; in 2016, Z. Šíblová (Šíblová, Moyzeová, 2019) confirmed the occurrence of 47 imagoes. Dolný et al. (2008) state a significant fluctuation in the number of local populations in the Czech Republic, from which we derive their metapopulation character. We also suppose a metapopulation structure for local populations in the Borská nížina lowland. The condition of the metapopulation concept is a high ability to disperse $L$. pectoralis (Jaeschke et al., 2013).

In Baden-Württemberg, there is a vertical range of sites from 172 to 700 m a.s.l. (Sternberg, Buchwald, 2000); 30\% of sites are located in the altitude range $500-600 \mathrm{~m}$ a.s.l., and $55 \%$ of sites are at an altitude of 630-700 m a.s.l. In Switzerland (Sternberg, Buchwald, 2000), $72 \%$ of the 47 sites are located between 400 and $600 \mathrm{~m}$ a.s.l. From the province of Trentino in the Dolomites of northern Italy (Macagno et al., 2012), the occurrence of a stable population of $L$. pectoralis is reported from a peatbog at an altitude of $930 \mathrm{~m}$ a.s.l. Most sites in Poland and Lithuania lie at an altitude of 160-180 m a.s.l. (Bernard et al., 2009; Kalninš, 2007). Slovak sites $(\mathrm{n}=38)$ of $L$. pectoralis have an average altitude of $282 \mathrm{~m}$ a.s.l.; the highest frequency of occurrence (mode) of sites is 200 $\mathrm{m}$ a.s.l, and hypsometric gradient also shows a significant values: minimum $98 \mathrm{~m}$ a.s.l. and maximum $863 \mathrm{~m}$ a.s.l. (Table 1). Occurrence in lowlands and mountain areas is the result of a preference for peatland habitats. It is necessary to monitor the dynamics of changes in the occurrence in the height (and latitude) gradient of species with high conservation value $L$. pectoralis.
In the recorded material from Slovakia, we found a solitary occurrence of $L$. pectoralis in 11 sites, and in the remaining 27 sites, it occurred (on the same day) together with other 49 species of dragonflies. The average number of species at the sites was $\bar{x}=10.07$ (including L. pectoralis); the highest was 20 species (Table 1). The high number of co-occurring species is also a result of the flight activity of the species, but some of them (e.g. Anax parthenope, Coenagrion ornatum, Ophiogomphus cecilia and Somatochlora metallica) occurred in low abundance, sporadically - only a few individuals. According to our results, Leucorrhinia pectoralis correlates only slightly with the species Cordulia aenea and Coenagrion ornatum (Fig. 2). Dragonflies Somatochlora flavomaculata, Anax imperator and Libellula quadrimaculata form a transition to a species-rich cluster of eutrophic aquatic habitat species. According to our initial PCA, L. pectoralis is not part of a cluster of typical peatland species as reported by Sternberg and Buchwald (2000), for example, Coenagrion hastulatum, Aeshna juncea, Libellula quadrimaculata, Leucorrhinia rubicunda, Leucorrhinia dubia and Sympetrum danae. The analysis of the coenotic position of L. pectoralis (we used NMDS using the Bray-Curtis dissimilarity index) showed the position of Leucorrhinia pectoralis near the intersection of the ordination axes (Fig. 3) as a weak habitat preference for a certain odonatocoenosis. A positive correlation to sphagnophilic species Libellula quadrimaculata, Leucorrhinia rubicunda, L. dubia, Sympetrum danae, etc. is indicated. When using NMDS, there is a certain loss of information, see Material and methods. Its value is for our two selected dimensions (ordination axes) SCV $=0.16$, which is according to Dexter et al. 
(2018) the value of a good ordination model without the risk of misinterpretation.

For dragonfly L. pectoralis we recorded in several types of habitats, larvae and exuviae were found only in seven sites. We derived 17 habitat variables from the sites of L. pectoralis, especially categorical variables. We assumed that some factors would show collinearity, which was confirmed for the variables habitat type (interdunal ponds and temporary type of water surface), land use (combination of arable land/forest), population type (metapopulation - no), and vegetation (tall riparian vegetation). Obviously, when processing metadata, the choice of factors is problematic. This was also confirmed (by the Monte Carlo permutation test), so seven factors were statistically recorded. Using the forward selection of explanatory (environmental) variables method, we found the factors with the least mutual correlation (forest, $p=0.006$ and altitude, $\mathrm{p}=0.016)$. We used six site variables in the RDA ordination graph (Fig. 4), which explain $\mathrm{R}^{2}=32.13 \%$ of the variability in the species data $\left(\mathrm{R}_{\text {adj }}^{2}=11.77 \%\right)$. We verified the significance of our model by testing all ordination axes $(\mathrm{p}=0.052)$, that is just on the border of statistical significance of the influence of selected factors on species data. The occurrence of $L$. pectoralis is positively correlated with factors as forest landscape $(\mathrm{p}=0.0063)$, because especially they preferred peatlands ( $r$ $=0.61, \mathrm{p}=0.0058)$. They have been destroyed or are fragmented in agricultural land. The complexity factor $(r=0.94, p$ $=0.0003$ ) expresses the representation of life forms and height stratification of vegetation in habitats with the occurrence of L. pectoralis. According to Randlkofer et al. (2010), vegetation complexity significantly influenced by species diversity of plant communities. In Lithuania (Kalninš, 2007), the highest frequency of $L$. pectoralis had habitats of oxbow lakes ( 21 sites) and eutrophic lakes ( 44 sites) with vegetation of the Magnopotamion and Hydrocharition type, having the character of peat. In our study, Leucorrhinia pectoralis does not show affinity for altitude $(\mathrm{r}=-0.00, \mathrm{p}=0.8472)$, which is determined by the altitude of suitable (peatland) habitats - conditions. As confirmed in a study by Jaeschke et al. (2013), will be the conservation of peatland habitats under conditions of climate change limiting the conservation of $L$. pectoralis populations. Using the models of boosted regression tree (BRT) model and GLM, the authors predict a $30 \%$ loss of the present distribution by 2035 . The decline of the species will be evident especially in southern and central Europe with the shift of sites to foothills and mountains. According to the BRT model, the forecast for 2050 assumes a centre of expansion in the north Poland, southern Scandinavia, the Baltics and Karelia. The extreme situation is predicted by the GLM; the European occurrence of $L$. pectoralis will be concentrated in two centres East Pomerania and Baltic-Karelia. In this context, the study by Buczyńska and Buczyński (2019) examined habitat characteristics important for L. pectoralis, for example, area of water surface, perimeter of the pit, cover of peatbog Sphagnum sp. and cover of macrophytic vegetation of pits after peat extraction. The analysis confirmed the key properties of habitats, also artificially created, are suitable for the reproduction of Leucorrhinia pectoralis. They are the $\mathrm{pH}$ of water, the cover of peatlands Sphagnum sp. and the circumference (size) of the water surface. These results are important for the conservation management of $L$. pectoralis as an umbrella species.

\section{Conclusion}

Between 1961 and 2020, the occurrence of the species of Community interest $L$. pectoralis was found in Slovakia in 38 sites in 112 records in the number of 707 imagoes, which is a comparable number with other Central European countries. Reproduction was confirmed in only few sites by finding larvae and exuviae. Most sites with the occurrence of $L$. pectoralis are located in the Záhorská nížina lowland, 213-351 $\mathrm{m}$ a.s.l. The dragonfly $L$. pectoralis occurs in the community as a dominant species, and the average number of species of dragonflies in sites with the occurrence of $L$. pectoralis was 10 species. We found a coenotic affinity for peat species $L i$ bellula quadrimaculata, Leucorrhinia rubicunda, L. dubia and Sympetrum danae. We evaluated 17 environmental variables for sites with occurrence of Leucorrhinia pectoralis, and after adjustment, we left six of them. We confirmed (by using a GLM) a statistically significant preference for the localization of L. pectoralis habitats: (i) the forest landscape $(\mathrm{r}=0.62, \mathrm{p}=$ 0.0063 ), (ii) the presence of submerged, emergent and macrophytic vegetation $(\mathrm{r}=0.94, \mathrm{p}=0.0003)$ and (iii) the preferences of peatbog habitats $(\mathrm{r}=0.61, \mathrm{p}=0.0058)$. By evaluating the basic criteria for umbrella species, Czachorowski et al. (2000) proposed to classify $L$. pectoralis as an umbrella species. Our results confirmed several properties required of umbrella species. They are easy determination of males and females, territoriality of males, preferences of peatland-type habitats with present macrophytic vegetation, two-year development of larvae and creation of species-rich communities of dragonflies with $L$. pectoralis reported in the literature. Therefore, we recommend continuing to use L. pectoralis as an umbrella species in conservation management. For the management of the population of L. pectoralis, we propose to identify suitable breeding sites that meet the habitat requirements of the species (peatlands with stands of Sphagnum spp. and sufficient water area). Leucorrhinia pectoralis has a high dispersion potential, and local populations can form a metapopulation structure, which is important for the conservation management of the species. The area that meets the above conditions is the Záhorská nížina lowland. The suitable spatial distribution of sites can also be supplemented by artificially created aquatic habitats. The regional biodiversity of plant and aquatic insect species, who have lived in peatlands and are bog specialists, would be significantly enhanced.

\section{Acknowledgements}

The contribution was created thanks to the support of VEGA project no. 2/0011/21 Landscape ecological aspects of green and blue infrastructure in creating the optimal spatial basis of ecologically stable areas in urbanized landscape.

\section{References}

Bernard, R., Buczyński, P., Tończyk, G. \& Wendzonka J. (2009). Atlas rozmieszczenia ważek (Odonata) w Polsce. Poznań: Bogucki Wydawnictwo Naukove.

Blaškovič, T. (2007). Diverzita vážok (Odonata) vybraných navrhovaných území európskeho významu Borskej nížiny. Správa z terénneho výskumu v roku 2007 pre projekt LIFE 05 NAT/SK/000112 WETREST.

Boudot, J.-P. \& Kalkman V.J. (Eds.) (2015). Atlas of the European dragonflies and damselflies. Uitgeveri: KNNV Publishing. 
Buczyńska, E. \& Buczyński P. (2019). Aquatic insects of man-made habitats Environmental factors determining the distribution of Caddisflies (Trichoptera), Dragonflies (Odonata), and Beetles (Coleoptera) in Acidic Peat Pools. J. Insect Sci., 19(1), 1-15. DOI: 10.1093/jisesa/iez005.

Conelly, L.M. (2012). Correlations. Medsurg Nursing, 21(3), 171-172. https:// www.researchgate.net/ publication/230621408

Czachorovski, S., Buczyński, P., Walczak, U. \& Pakulnicka J. (2000). Gatunki osłonowe (parasolowe) w ochronie owadów. Pregląd Przyrodniezy, 11(2-3), 139-148.

David, S. \& Šácha D. (2019). Komentovaný seznam vážek (Odonata) Slovenské republiky. Ochrana Prírody, 33, 49-78.

Dexter, E., Rollwagen-Bollens, G. \& Bollens S.M. (2018). The trouble with stress: A flexible method for the evaluation of nonmetric multidimensional scaling. Limnol. Oceanogr.: Methods, 16 (7), 434-443. DOI: 10.1002/lom3.10257.

Dijkstra, K.D. \& Lewington R. (2006). Field guide to the dragonflies of Britain and Europe including western Turkey and north-western Africa. Gilligham: British Wildlife Publishing.

Dolný, A., Bárta, D., Waldhauser, M., Holuša, O., Hanel, L. \& Lízler R. (2008). Vážky České republiky: Ekologie, ochrana a rozšírení. Vlašim: ČSOP.

Dolný, A. \& Harabiš F. (2004). K aktuálnimu výskytu vážky jasnoskvrnné Leucorrhinia pectoralis (Odonata: Libellulidae) v české části Slezska. In L. Hanel (Ed.), Vážky 2004: Sborník referátů VII. celostátniho semináře odonatologů v Krušných horách (pp. 17-21). Vlašim: ZO ČSOP.

ESRI (2011). ArcGIS Desktop: Release 10. Redlands: Environmental Systems Research Institute.

Harabiš, F. \& Dolný A. (2012). Human altered ecosystems: Suitable habitats as well as ecological traps for dragonflies (Odonata): The matter of scale. J. Insect Conserv., 16(1), 121-130. DOI: 10.1007/s10841-011-9400-0.

Harabiš, F., Dolný, A. \& Plášek V. (2006). Could the fen rise in a place of astrip mine lake? Environmental changes and biological assessment III. Scripta Facultatis Rerum Naturalium Universitatis Ostraviensis, 163, 212-214.

Jaeschke, A., Bittner, T., Reineking, B. \& Beierkuhnlein C. (2013). Can they keep up with climate change? - Integrating specific dispersal abilities of protected Odonata in species distribution modeling. Insect Conservation and Diversity, 6(1), 93-103. DOI: 10.1111/j.1752-4598.2012.00194.x.

Kalivodová, M., Kanka, R., Miklós, P., Hulejová Sládkovičová, V. \& Žiak D. (2018). Importance of Wetland Refugia in Agricultural Landscape Provided Based on the Community Characteristics of Small Terrestrial Mammals. Ekológia (Bratislava), 37(4), 358-368. DOI: 10.2478/eko2018-0027.

Kalkman, V.J., Boudot, J.-P., Bernard, R., Conze, K.-J., De Knijf, G., Dyatlova, E., Ferreira, S., Jović, M., Ott, J., Riservato, E. \& Sahlen G. (2010). European Red List of Dragonflies. Luxembourg: Publications Office of the European Union.

Kalninš, M. (2007). Protected aquatic insects of Latvia - Leucorrhinia pectoralis (Charpentier, 1825) (Odonata: Libellulidae). Latvijas Entomologs, 44, 26-32.

Kietzka, G.J., Pryke, J.S., Gaigher, R. \& Samways M.J. (2019). Applying the umbrella index across aquatic insect taxon sets for freshwater assessment Ecological Indicators, 107, 105655. DOI: 10.1016/j.ecolind.2019.105655.

Lambeck, R.J. (1997). Focal Species: A Multi-Species Umbrella for Nature Conservation. Conserv. Biol., 11(4), 849-856. DOI: 10.1046/j.15231739.1997.96319.x.

Losos, B., Gulička, J., Lellák, J. \& Pelikán J. (1985). Ekologie živočichů. Praha: SPN.

Macagno, A.L.M., Gobbi, M. \& Lencioni V. (2012). The occurrence of Leucorrhinia pectoralis (Charpentier, 1825) (Odonata, Libellulidae) in Trentino (Eastern Italian Alps). Stud. Trentini Sci. Nat., 92, 33-36.
Manci, C.O. \& Popescu I.E. (2016). Fifty years later: the rediscovery of Leucorrhinia pectoralis (Odonata: Libellulidae) in Romania. Trav. Mus. Natl. Hist. Nat., 59(2), 109-119.

Mauersberger, R. (2010). Leucorrhinia pectoralis can coexist with fish (Odonata: Libellulidae). International Journal of Odonatology, 13, 193-204. 10.1080/13887890.2010.9748374.

Mocsáry, S. (1896). Ordo Pseudo-neuroptera. In J. Paszlavszky (Ed.), 1900 - Fauna Regni Hungariae, III (Arthropoda) (pp. 23-32). Budapest: K.M. Természettudományi Társulat.

Randlkofer, B., Obermaier, E., Hilker, M. \& Meiners T. (2010). Vegetation complexity - The influence of plant species diversity and plant structures on plant chemical complexity and arthropods. Basic and Applied Ecology, 11(5), 383-395. DOI: 10.1016/j.baae.2010.03.003.

Rannap, R., Kaart, T., Briggs, L. \& De Vries W. (2011). Habitat requirements of Pelobates fuscus and Leucorrhinia pectoralis. Project report: "Securing Leucorrhinia pectoralis and Pelobates fuscus in the northern distribution area in Estonia and Denmark". LIFE08NAT/EE/000257, Tallinn.

Seddon, P. \& Leech T. (2008). Conservation short cut, or long and winding road? A critique of umbrella species criteria. Oryx, 42(2), 240-245. DOI: 10.1017/S003060530806119X.

Schoor, M. \& Paulson D. (2020). World Odonata List. Slater Museum of Natural History, University of Puget Sound, Tacoma, USA: last re vision 10 November 2020. https://www.pugetsound.edu/academics/academicresources/slater-museum/biodiversity-resources/dragonflies/worldodonata-list $2 /$.

StatSoft, Inc. (2004). Statistica (data analysis software system), version 7. Www.StatSoft.Cz.

Sternberg, K. \& Buchwald R. (2000). Die Libellen Baden-Wuerttembergs Band 2: Grosslibellen (Anisoptera). Stuttgart: Verlag Ulmer.

Šácha, D. (2015a). Vážky. In M. Janák, J. Černecký \& A. Saxa (Eds.), Monitoring živočíchov európskeho významu $v$ Slovenskej republike. Výsledky a hodnotenie za roky 2013-2015 (pp. 92-102). Banská Bystrica: ŠOP SR

Šácha, D. (2015b). Metodika monitoringu druhu európskeho významu vážka jednoškvrnná (Leucorrhinia pectoralis). In A. Saxa, J. Černecký, J. Galvánková, M. Mútňanová, A. Balážová \& M. Gubková-Mihaliková (Eds.), Príručka metód monitoringu biotopov a druhov európskeho významu (pp. 56-57). Banská Bystrica: ŠOP SR.

Šácha, D., David, S., Waldhauser, M., Buczyński, P., Tończyk, G., Makomaska-Juchiewicz, M., Martynov, A.V., Miklós G. Heltai, M.G., Manci, C.O. \& Jović M. (2014). Draft Red list of dragonflies (Odonata) of the Carpathian Mts. In J. Kadelčík (Ed.), Carpathian red list of forest habitats and species Carpathian list of invasive alien species (pp. 172-185). Banská Bystrica: ŠOP SR. http://www.cwi.sk/files/zbornik_cervene_zoznamy_ final.pdf.

Šácha, D. \& Šíbl J. (2000). K ochrane vážok (Odonata) Záhoria. Ochrana Prírody, 18, 133-143.

Šíbl, J. (2001). K rozšíreniu Leucorrhinia pectoralis (Odonata: Libellulidae) na západnom Slovensku. Entomofauna Carpathica, 13, 3-4.

Šíblová, Z. \& Moyzeová M. (2019). Výskum vážok (Odonata) mokradí Borskej nížiny (Dragonflies and Damselflies (Odonata) research of wetlands in the area of Borská nížina lowland). Ekologické Štúdie, 10, 119-126.

Šmilauer, P. \& Lepš J. (2014). Multivariate Analysis of Ecological Data using Canoco5. Cambridge: Cambridge University Press.

ter Braak, C.J.F. \& Šmilauer P. (2012). Canoco References Manual and User's: Guide to Canoco for Windows. Ithaca: Microcomputer Power.

Trpiš, M. (1969). Vážky (Odonata) východného Slovenska. Zborník Slovenského Národného Múzea, 12, 31-38. 


\section{Appendix}

Overview of research and basic data on sites with confirmed occurrence of L. pectoralis in Slovakia.

\begin{tabular}{|c|c|c|c|c|c|c|c|}
\hline Year & LOC & I & $\mathrm{E} / \mathrm{L}$ & SUM & CAD_AREA & WGS-84 & ALT \\
\hline $1987-1988$ & $1 / 4$ & 7 & 0 & 7 & Bohunice & $48^{\circ} 21^{\prime} 26.09^{\prime \prime} \mathrm{N} 18^{\circ} 46^{\prime} 11.04^{\prime \prime} \mathrm{E}$ & 480 \\
\hline 2000 & $2 / 1$ & 1 & 0 & 1 & Sekule & $48^{\circ} 35^{`} 51.7 \mathrm{~N} 16^{\circ} 59^{\prime} 26.47 \mathrm{E}$ & 151 \\
\hline 2000 & $3 / 1$ & 2 & 0 & 2 & Plavecký Peter & $48^{\circ} 33^{`} 5.07 \mathrm{~N} 17^{\circ} 18^{`} 1.36 \mathrm{E}$ & 195 \\
\hline $2000-2002$ & $4 / 2$ & 14 & 0 & 14 & Lakšárska Nová Ves & $48^{\circ} 33^{\prime} 19.09 \mathrm{~N} 17^{\circ} 9^{\prime} 15.18 \mathrm{E}$ & 218 \\
\hline $1998-2002$ & $5 / 3$ & 1 & 2 & 3 & Lakšárska Nová Ves & $48^{\circ} 33^{\circ} 40.42 \mathrm{~N} 17^{\circ} 10^{\circ} 7.47 \mathrm{E}$ & 224 \\
\hline $2000-2002$ & $6 / 2$ & 10 & 0 & 10 & Lakšárska Nová Ves & $48^{\circ} 34^{\prime} 18.54 \mathrm{~N} 17^{\circ} 34^{`} 10.44 \mathrm{E}$ & 225 \\
\hline 1998 & $7 / 1$ & 2 & 0 & 2 & Svätý Jur & $48^{\circ} 15^{\prime} 24.67 \mathrm{~N} 17^{\circ} 9^{\prime} 22.36 \mathrm{E}$ & 465 \\
\hline $2000-2018$ & $8 / 9$ & 69 & 0 & 69 & Lakšárska Nová Ves & $48^{\circ} 36^{\prime} 15.08 \mathrm{~N} 17^{\circ} 10^{`} 12.41 \mathrm{E}$ & 200 \\
\hline $2000-2001$ & $9 / 2$ & 60 & 0 & 60 & Láb & $48^{\circ} 22^{\prime} 27.51 \mathrm{~N} 16^{\circ} 57^{\prime} 22 \mathrm{E}$ & 148 \\
\hline 2000 & $10 / 1$ & 2 & 0 & 2 & Plavecký Štvrtok & $48^{\circ} 23^{\circ} 49.68 \mathrm{~N} 16^{\circ} 58^{`} 16.02 \mathrm{E}$ & 155 \\
\hline $2000-2019$ & $11 / 10$ & 114 & 4 & 118 & Šajdíkové Humence & $48^{\circ} 38^{\circ} 26.48 \mathrm{~N} 17^{\circ} 16^{\prime} 3.97 \mathrm{E}$ & 200 \\
\hline 2000 & $12 / 1$ & 7 & 0 & 7 & Šajdíkové Humence & $48^{\circ} 38^{`} 33.28 \mathrm{~N} 17^{\circ} 16^{`} 39.87 \mathrm{E}$ & 200 \\
\hline 2000 & $13 / 3$ & 4 & 0 & 4 & Čuňovo & $48^{\circ} 3^{\prime} 9.1 \mathrm{~N} 17^{\circ} 10^{\prime} 23.94 \mathrm{E}$ & 128 \\
\hline 1999-2014 & $14 / 6$ & 3 & 3 & 6 & Klin & $49^{\circ} 25^{\circ} 43.18 \mathrm{~N} 19^{\circ} 29^{`} 55.27 \mathrm{E}$ & 618 \\
\hline 1961 & $15 / 1$ & 2 & 0 & 2 & $\mathrm{Rad}$ & $48^{\circ} 27^{`} 3.73 \mathrm{~N} 21^{\circ} 52^{`} 4.75 \mathrm{E}$ & 104 \\
\hline 2001 & $16 / 1$ & 2 & 0 & 2 & Muránska Lehota & $48^{\circ} 43^{\circ} 46.41 \mathrm{~N} 20^{\circ} 2^{\prime} 44.42 \mathrm{E}$ & 383 \\
\hline $2017-2019$ & $17 / 3$ & 8 & 0 & 8 & Číčov & $47^{\circ} 46^{`} 36.73 \mathrm{~N} 17^{\circ} 43^{`} 53.31 \mathrm{E}$ & 112 \\
\hline $2013-2014$ & $18 / 5$ & 30 & 0 & 30 & Strážne & $48^{\circ} 22^{`} 52.68 \mathrm{~N} 21^{\circ} 51^{`} 24.37 \mathrm{E}$ & 98 \\
\hline $2014-2019$ & $19 / 3$ & 4 & 0 & 4 & Párnica & $49^{\circ} 11^{`} 55.5 \mathrm{~N} 19^{\circ} 12^{`} 55.89 \mathrm{E}$ & 453 \\
\hline 2008 & $20 / 1$ & 2 & 0 & 2 & Rusovce & $48^{\circ} 3^{`} 1.48 \mathrm{~N} 17^{\circ} 10^{`} 19.67 \mathrm{E}$ & 130 \\
\hline 2007 & $21 / 1$ & 1 & 0 & 1 & Budiš & $48^{\circ} 52^{`} 29 \mathrm{~N} 18^{\circ} 45^{\circ} 47.91 \mathrm{E}$ & 480 \\
\hline 2008 & $22 / 1$ & 1 & 0 & 1 & Komárno & $47^{\circ} 48^{`} 22.22 \mathrm{~N} 18^{\circ} 8^{`} 1.01 \mathrm{E}$ & 107 \\
\hline 2007 & $23 / 1$ & 1 & 0 & 1 & Mlynčeky & $49^{\circ} 10^{\prime} 11.15 \mathrm{~N} 20^{\circ} 23^{\circ} 43.62 \mathrm{E}$ & 674 \\
\hline 2018-2019 & $24 / 5$ & 6 & 0 & 6 & Vyšný Blh & $48^{\circ} 28^{\prime} 19.95 \mathrm{~N} 20^{\circ} 8^{\prime} 13.18 \mathrm{E}$ & 415 \\
\hline $2009-2019$ & $25 / 11$ & 85 & 13 & 98 & Ostruňa & $49^{\circ} 20^{`} 30.69 \mathrm{~N} 20^{\circ} 13^{`} 19.83 \mathrm{E}$ & 821 \\
\hline 2011 & $26 / 1$ & 7 & 0 & 7 & Moravský Ján & $48^{\circ} 34^{`} 34.31 \mathrm{~N} 16^{\circ} 57^{`} 18.01 \mathrm{E}$ & 150 \\
\hline 2013 & $27 / 1$ & 0 & 3 & 3 & Detvianská Huta & $48^{\circ} 34^{\prime} 25.21 \mathrm{~N} 19^{\circ} 36^{\prime} 28.22 \mathrm{E}$ & 863 \\
\hline $2013-2017$ & $28 / 6$ & 7 & 8 & 15 & Zázrivá & $49^{\circ} 16^{`} 7.89 \mathrm{~N} 19^{\circ} 8^{`} 40.88 \mathrm{E}$ & 657 \\
\hline 2015 & $29 / 2$ & 26 & 0 & 26 & Svätá Mária & $48^{\circ} 26^{\prime} 10.55 \mathrm{~N} 21^{\circ} 49^{`} 38.18 \mathrm{E}$ & 100 \\
\hline 2001-2019 & $30 / 7$ & 44 & 0 & 44 & Malacky & $48^{\circ} 28^{‘} 51.44 \mathrm{~N} 17^{\circ} 3^{`} 49.87 \mathrm{E}$ & 175 \\
\hline $2001-2020$ & $31 / 6$ & 97 & 2 & 99 & Šaštín & $48^{\circ} 36^{`} 48.3 \mathrm{~N} 17^{\circ} 8^{`} 53.76 \mathrm{E}$ & 205 \\
\hline 2020 & $32 / 1$ & 1 & 0 & 1 & Šránek & $48^{\circ} 37^{`} 53.97 \mathrm{~N} 17^{\circ} 22^{`} 1.87 \mathrm{E}$ & 200 \\
\hline 2002 & $33 / 1$ & 2 & 0 & 2 & Čunovo & $48^{\circ} 2 ` 24.32 \mathrm{~N} 17^{\circ} 11^{`} 23.61 \mathrm{E}$ & 129 \\
\hline $2001-2020$ & $34 / 3$ & 36 & 0 & 36 & Riadok & $48^{\circ} 28^{`} 3.9{\mathrm{~N} 17^{\circ} 3}^{\circ} 38.36 \mathrm{E}$ & 198 \\
\hline 2001-2002 & $35 / 2$ & 29 & 0 & 29 & Čáry & $48^{\circ} 40^{\prime} 31.19 \mathrm{~N} 17^{\circ} 3^{\prime} 21.17 \mathrm{E}$ & 164 \\
\hline 2001 & $36 / 1$ & 11 & 0 & 11 & Čáry & $48^{\circ} 40^{`} 56.11 \mathrm{~N} 17^{\circ} 3^{\prime} 41.72 \mathrm{E}$ & 164 \\
\hline 2001 & $37 / 1$ & 1 & 0 & 1 & Čáry & 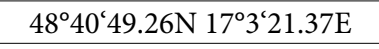 & 164 \\
\hline 2001 & $38 / 1$ & 8 & 0 & 8 & Brodské & $48^{\circ} 40^{`} 52.15 \mathrm{~N} 17^{\circ} 2^{`} 31.51 \mathrm{E}$ & 163 \\
\hline
\end{tabular}

Notes: Year, research period; LOC, serial number of the sites/number of finds; I, number of imagoes; E/L, number of exuviae/larvae; SUM, number of all individuals; CAD_AREA, cadastral area; WGS-84, sites coordinates; ALT, altitude. 